Our Nature (2008)6: 67-77

\title{
Status and Conservation of Lowland Terai Wetlands in Nepal
}

\author{
S. Jha \\ Department of Botany, Post Graduate Campus, \\ Tribhuvan University, Biratnagar, Nepal \\ Email: jhasasinath@yahoo.com
}

Received: 23.09.2008, Accepted: 15.10.2008

Keywords: Lowland wetland, Nepal

Known as "Simsar" in Nepal, wetlands are those areas which lie between the land and deepwater and remian waterlogged or submerged under water, seasonally or throughout the year. Generally the land is so muddy that one cannot easily walk over it, and water is so deep that one can neither swim nor get drowned. River floodplains, shallow margins of lakes and reservoirs, shallow and seasonal ponds, islands in rivers, deepwater paddy fields, and seacoasts are typical examples of wetlands.

Wetlands are essential for the free ecosystem services that they provide to the human community. The most obvious are maintenance or improvement of water quality, groundwater discharge and recharge, erosion control, flood protection and flow stabilization, storm dampening, healthy ecosystem functions, soil building, foodchain production, nutrient cycling and biogecochemical processes, habitat for wildlife, sites for research and environmental education, cultural heritage, open space preservation, aesthetics, tourism and recreation. They are also important because attention has been turned recently to using wetland systems and the plant species occurring therein as bio-energy sources and also for use in pollution abatement projects to filter sewage, agricultural runoff, leachate from landfills, and acid mine drainage mitigation (Brooks, 1989; Oliver and Hill 1998). It is the constellation of these and other functions and values that the wetlands are recognized as the 'Kidneys of the landscape' or called as 'biological supermarkets'.

Unfortunately, the wetlands are being degraded today mainly due to pollution from sewage and industrial effluents, and from overexploitation of resources. The wetlands are rapidly disappearing because of the general notion that they are waterlogged and unproductive lands which harbour disease-carrying insects, pests and poisonous snakes. They are drained and/or filled for agriculture, human settlements and industries besides being rapidly silted due to large scale deforestation in surrounding areas, and they are also being dried up in many places as rivers are dammed and channelized for the generation of hydroelectricity and other purposes.

\section{Wetland types}

Nepal extends along the Great Himalayan Range between the latitudes $26^{\circ} 20^{\prime} \mathrm{N}$ to $30^{\circ} 27^{\prime} \mathrm{N}$, and longitudes $80^{\circ} 04^{\prime} \mathrm{E}$ to $88^{\circ} 12^{\prime} \mathrm{E}$, covering a distance of $885 \mathrm{~km}$ (form east to 
west), average width of $193 \mathrm{~km}$ (from south to north), and estimated area of $147181 \mathrm{sq}$ $\mathrm{km}$. The elevation of the country rises from $60 \mathrm{~m}$, mean sea level in the southern Terai to the crest of the Himalaya (the home of perpetual snow) reaching up to $8848 \mathrm{~m}$ at Mt. Sagarmatha (Everest) in the north. About $70 \%$ of the country is drained by four major river systems originating in the higher Himalayan Zone: Sapta Koshi in the eastern part, Sapta Gandaki (Narayani) in the central part, Karnali in the western part and Mahakali in the far-western part of the country. Several medium size rivers originate in the midland zone or in the Mahabharat range (Rapti, Bagmati, Kamala, Kankai, Tinau, etc.) whereas small rivers mostly seasonal in character originate from the Siwalik (Churia) ranges and dissect the Terai plain.

Nepal has only freshwater wetlands. The Department of Agriculture Development (1992) has estimated that wetlands occupy 743563 ha or roughly $5 \%$ of Nepal's total land area (Table 1).

Table 1. Estimated area of various wetlands in Nepal (DOAD 1992)

\begin{tabular}{|l|c|c|}
\hline Wetland types & Estimated area (ha) & Percent \\
\hline Rivers & 395000 & 53.1 \\
\hline Lakes & 5000 & 0.7 \\
\hline Reservoirs & 1380 & 0.2 \\
\hline Marshy lands & 12000 & 1.6 \\
\hline Village ponds & 5183 & 0.7 \\
\hline Paddy fields & 325000 & 43.7 \\
\hline Total & 743563 & 100.00 \\
\hline
\end{tabular}

The country has approximately 6000 rivers and rivulets, including permanent and seasonal rivers, streams and creeks (WECS 2002). The major river systems - Mahakali, Karnali, Gandaki and Koshi - originate in the high altitude snow covered mountains and are 'permanent' in nature. On the other hand, rivers/rivulets originating in Siwalik/Terai are seasonal in nature and major water flow exists only during the monsoon (mid-June to October). All the rivers of Nepal drain into the Ganges River System in India through the Terai region, giving rise to ox-bow lakes or ponds and floodplains.

The lentic water-bodies are classified as glacial, tectonic and ox-bow types depending on their geological origin. The lakes that occur above $3500 \mathrm{~m}$, msl are mostly of glacial origin. They are generally moraine dammed, but some like the Thulagi glacial lake of the Manaslu area are dammed by an ice body (Hanisch et al. 1998). The largest glacial lake is Rara (1036 ha) located at an altitude of $3000 \mathrm{~m}$, msl, followed by Shey Phoksundo (452 ha) and Tilicho (4919 m,. msl; area $40 \mathrm{ha}$ ) lakes. Lakes and ponds of mid-hill and mountain regions (below $3000 \mathrm{~m}, \mathrm{msl}$ ) of Nepal are considered tectonic in origin and are thought to have been created in depressions caused by land subsidence. The famous lakes of Pokhara valley - Phewa, Begnas, Rupa, Khaste, Dipang, Gunde, Kaalpokhari and Maidi belong to the tectonic category. Mostly the ox-bow lakes and ponds occur in the Terai plain of Nepal. In many places these lakes / ponds have converted into marshes (ghols) or swamps due to siltation and plant succession. Marshes are extensive near the streams and rivers of the Terai floodplains.

Some notable hotsprings (geothermal springs including Tatopani in Sindhupalchok district and Tatopani in Annapurna Conservation Area) occur in mid-hills and mountains. Alpine and Tundra type wetlands occur above $4000 \mathrm{~m}$, msl. These wetlands are restricted to alpine meadows and shrubberies, where 
environmental factors such as low temperature, high acidity, low nutrient supply, waterlogging and oxygen deficiency slow the decomposition of organic matter and favour peat formation.

The human made wetlands in Nepal include reservoirs, aquaculture ponds, agricultural lands and irrigation canals.

\section{Physico-chemical properties}

In high altitude lakes of Nepal, Loffler (1969) reported the dominance of calcium among cations, low chloride and less than 1 $\mu \mathrm{g} / 1$ phosphorus. Aizaki et al. (1978) reported $<6 \mu \mathrm{g} / \mathrm{l}$ phosphorus in the lake Tilicho and considered this level to be limiting to the lake productivity. Similarly, James and Hubbick (1969) found the low level of nitrogen as limiting factor in the high altitude lakes of Nepal. According to McEachern (1994), light and temperature are the most predominate limiting factors for the lake productivity at high altitudes.

In highland $(>2000 \mathrm{~m})$ rivers of Nepal, Ormerod et al. (1996) reported the $\mathrm{pH}$ range between 7.3 to $8,0.4$ to $1.4 \mathrm{mg} / 1$ chloride, 0.06 to $0.28 \mathrm{mg} / 1$ nitrate, and 0.02 to 0.04 $\mathrm{mg} / \mathrm{l}$ phosphate. Dangol and Lacoul (1996) reported 6.9 to $7.2 \mathrm{pH}, 0.15$ to $0.38 \mathrm{mg} / 1$ nitrate, 0.22 to $0.62 \mathrm{mg} / 1$ phosphate, and 6.0 to $7.3 \mathrm{mg} / 1$ dissolved oxygen in the midland (1000-2000 m) rivers of Nepal. McEachern (1994) reported $8.4 \mathrm{pH}, \quad 0.23 \quad \mathrm{mg} / \mathrm{l}$ phosphate, and $8.5 \mathrm{mg} / 1$ dissolved oxygen in Narayani, a lowland $(<1000 \mathrm{~m})$ river of Nepal. WBS Nepal (2005) reported $7 \mathrm{pH}$, $79.1 \mathrm{~m} \mathrm{mhos} / \mathrm{cm}$ conductivity, $9 \mathrm{mg} / 1$ total suspended solids, $73 \mathrm{mg} / \mathrm{l}$ total dissolved solids, $67 \mathrm{mg} / \mathrm{l}$ total hardness as $\mathrm{CaCO}_{3}$, $74.63 \mathrm{mg} / \mathrm{l}$ total alkalinity as $\mathrm{CaCO}_{3}, 1 \mathrm{mg} / 1$ chloride, $0.12 \mathrm{mg} / \mathrm{l}$ ammonia-nitrogen, $<0.05 \mathrm{mg} / 1$ nitrate-nitrogen, $<0.01 \mathrm{mg} / 1$ nitrite nitrogen, $0.01 \mathrm{mg} / \mathrm{l}$ dissolved phosphate-phosphorus, $0.05 \mathrm{mg} / \mathrm{l}$ total phosphate-phosphorus, $<0.005 \mathrm{mg} / 1$ arsenic, $3.84 \mathrm{mg} / 1$ iron, $0.50 \mathrm{ng} / 1$ manganese, 0.40 $\mathrm{mg} / \mathrm{l}$ potassium, $<00.01 \mathrm{mg} / \mathrm{l}$ chromium, $<0.001 \mathrm{mg} / \mathrm{l}$ cadmium, $6.62 \mathrm{mg} / 1$ dissolved oxygen, $6.5 \mathrm{mg} / 1$ chemical oxygen demand, $1.51 \mathrm{mg} / \mathrm{l}$ biological oxygen demand, and $18.16 \mu \mathrm{g} / \mathrm{m}^{3}$ chlorophyll a in lake water, and $1.82 \mathrm{mg} / \mathrm{g}$ total nitrogen, $2.53 \%$ organic carbon, $6.13 \mu \mathrm{g} / \mathrm{g}$ available phosphorus, and $196 \mu \mathrm{g} / \mathrm{g}$ available potassium in the base layer of soil of the Beeshazar lake

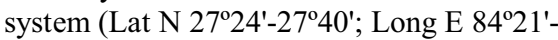
$84^{\circ} 24^{\prime}$, average altitude $286 \mathrm{~m}, \mathrm{msl}$ ) in central Nepal. Sharma (1996) studied the physico-chemical properties of the Koshi river downstream water and found it to be clean with healthy and productive environment for its biotic componenets on the basis of annual averages of conductivity (211 $\mu \mathrm{s} / \mathrm{cm}), \mathrm{pH}$ (slightly alkaline), free $\mathrm{CO}_{2}$ (5 ppm), dissolved oxygen (6.6 ppm), total alkalinity (50 ppm), fluoride (19.5 $\mathrm{ppm})$, and the magnitude of the ionic composition in the order: $\mathrm{Ca}(34 \mathrm{ppm})>\mathrm{Cl}$ $(23.8 \mathrm{ppm})>\mathrm{Na}(5.3 \mathrm{ppm})>\mathrm{NO}_{3}(2.4 \mathrm{ppm})$ $>\mathrm{Mg}(1.9 \mathrm{ppm})>\mathrm{K}(0.9 \mathrm{ppm})>\mathrm{PO}_{4}-\mathrm{P}(0.15$ ppm).

\section{Macrophytes}

Notable free-floating macrophytes of the lowland wetlands (Terai) in Nepal include Azolla imbricata, Eichhornia crassipes, Lemna perpusilla, Pistia stratiotes, and Spirodela polyrhiza, whereas common floating leafed species are Ludwigia adscendens, Marsilea crenata, Nelumbo nucifera, Nymphaea nouchali, $N$. pubescens, N. stellata, Nymphoides hydrophyllum, Sagittaria guyanensis and Trapa quadrispinosa. Both the free-floating and floating-leafed hydrophytes provide a nesting habitat for birds such as the 
Pheasant-tailed Jacana, Bronze-winged Jacana, and Purple Moorhen (Sankhala 1990).

The submerged hydrophytes found in Terai wetlands of Nepal include Aponogeton natans, Blyxa japonica, Callitriche stagnalis, Ceratophyllum demersum, Hydrilla verticillata, Ottelia alismodies, Potamogeton crispus, Utricularia aurea, and Vallisnaria natans. These submerged hydrophytes provide food for fish and a habitat for large numbers of invertebrates (especially crustaceans) and some birds such as Pintails (Anas acuta).

The common emergent hydrophytes of the Terai wetlands are Aeschynomene asper, Alternanthera philoxeroides, Arundinella bengalensis, Cyperus pilosus, Echinochloa, colona, Hygrophila auriculata, $H$. polysperma, Ipomoea carnea, subsp. fistulosa, Leersia hexandra, Ludwigia perennis, Monochoria hastata, Oryza rufipogon, Pandanus nepalensis, Persicaria barbata, P. lapathifolia, Phragmites karka, Phyllanthus reticulatus, Ranunculus sceleratus, Rumex dentatus, Sagittaria trifolia, Schoenoplectus grossus, Sesbania sesban, Spilanthes iabadicensis, Tamarix dioica,Typha angustifolia, T. elephantina, Veronica anagallis-aquatica, and Vetiveria zizanioides (Jha et al. 2004, 2005). The leaves and shoots of emergent hydrophytes provide food for grasshoppers and habitat for spiders and insects, including dragonflies and mantids. The seeds are picked by several migratory birds and when dispersed in water they are eaten by fish. These plants also provide nesting habitats for bitterns, Purple Heron, finches; roosts for Rosy Pastor, wagtails, and Purple Moorhen; and vantage perch for Ring-tailed Fishing Eagle, Purple Moorhen and Kingfishers (Sankhala 1990).
Seasonally, the macrophytic communities change considerably in tropical wetlands of the Indo-Gangetic plain (Rai and Sharma (1991). Drying of water in seasonally flooded areas during summer exposes the substrate and allows the germination of burried seeds of perennial emergents and annual mud-flat plants. After the arrival of monsoon, standing water returns and the mud-flat species disappear leaving only the emergents. The submerged species quickly reappear as their seeds readily germinate in standing water. The emergents increase in density and become dominant during the monsoon season, but with the decline in water level and ambient temperature in October-Nobember this community starts senescing. During winter, emergents have maximum biomass, carbohydrates and nutrients belowground particularly in rhizomes, and after the arrival of summer, there is a burst of shoot growth, which is fueled by photosynthesis and translocation of carbohydrates and other nutrients stored in their rhizomes (Bernard 1998).

Rai (1990) has reported that the percent frequency of bottom-rooted floating-leafed species attains the highest value in monsoon and lowest in winter, whereas the submerged species have the highest frequency in winter and lowest in monsoon in permanent wetlands of north Bihar (India).

Ambasht (1971) in an ecosystem analysis of a small pond in the Banaras Hindu University Campus (India) found highest density of 3400 plants $/ \mathrm{m}^{2}$ for small free-floating Azolla pinnata to about 200 plants $/ \mathrm{m}^{2}$ in emergent zone of Eleocharis plantaginea. This pond, free from any pollution, had $2.21 \mathrm{~kg} / \mathrm{m}^{2}$ dry biomass in shallow zone with emergent vegetation, and 
$0.57 \mathrm{~kg} / \mathrm{m}^{2}$ in floating-leafed Trapa bispinosa central zone. Energy concentration was highest in Eleocharis (3568 cal/g) followed by Trapa (2883 $\mathrm{cal} / \mathrm{g})$, and least $(2183 \mathrm{cal} / \mathrm{g})$ in Azolla.

In Ramgarh wetland of Gorakhpur (India), Sinha (1969) calculated $930 \mathrm{~g} / \mathrm{m}^{2} / \mathrm{yr}$ production in emergent zone, and a little over $100 \mathrm{~g} / \mathrm{m}^{2} / \mathrm{yr}$ in floating and submerged zones. In temperate climate of Srinagar (Kashmir, India), Kaul (1971) found 2800 $\mathrm{g} / \mathrm{m}^{2} / \mathrm{yr}$ productivity in the emergent, and $809 \mathrm{~g} / \mathrm{m}^{2} / \mathrm{yr}$ in floating zone of the famous Dal Lake.

\section{General biodiversity}

Wetlands are crucial for the conservation of both migratory species as well as several globally threatened biodiversity in Nepal, in addition that they support many species of flora and fauna including the endemics. In terms of flora, it is believed that $25 \%$ of the country's estimated 7000 vascular plant species are wholly or partially wetland dependent (Joshi and Joshi 1991). Nepal's wetlands also hold several species of wild cultivars and wild relatives of cultivated crops, including four species of wild paddy - Oryza granulata, O. nivara, O. officinalis and $O$. rufipogon - and two species of wild relatives of paddy - Hygrorhyza aristata and Leersia hexandra.

The globally threatened bird species that are wetland dependent include: (a) Critically endangered: Pink-headed duck (Rhodonessa carryophyllacea); Endangered: greater adjutant (Leptoptilos dubius), and lesser florican (Sypheotides indica), and (c) Vulnerable: Baikal teal (Anas formosa), swamp francolin (Frankolinus gularis), Baer's pochard (Aythya baeri), grey pelican (Pelecanus philippensis), Sarus crane (Grus antigone),
Indian Skimmer (Rynchops albicollis), black-necked crane (Grus nigricollis), lesser adjutant (Leptoptilos javanicus), and bandtailed fish eagle (Haliaeetus leucoryphus).

The key blobally threatened mammals in Nepal that are wetland dependent include: (a) Critically endangered: Pygmy hog (Sus salvanius); (b) endangered: Gangetic river dolphin (Platanista gangetica), wild water buffalo (Bubalus bubalis), greater onehorned rhinoceros (Rhinoceros unicornis), elephant (Elephas maximus), and tiger (Panthera tigris); and (c) Vulnerable: Indian smooth-coated otter (Lutrogale perspicillata), common otter (Lutra lutra), fishing cat (Prionailurus viverrinus), and barasingha (Cervus duvaucelii).

Among the wetland dependent globallythreatened reptiles of Nepal are: (a) critically endangered: Bengal roof turtle (Kachuga kachuga); (b) endangered: three-striped roof turtle (Kachuga dhongoka), elongated tortoise (Indotestudo elongata), and gharial (Gavialis gangeticus); (c) Vulnerable: broad-snouted crocodile (Crocodylus palustris), Crowned river turtle (Hardella thurjii), Indian eyed turtle (Morenia petersi), black pond turtle (Geoclemys hamiltonii), and three-keeled land tortoise (Melanochelys tricarinata).

Some nationally threatened fish fauna of Nepal include: (a) endangered: Sahar (Tor putitora), Jalkapor (Clupisoma garuwa, Ompak bimaculatus); (b) vulnerable: Katle (Neolissocheilus hexagonolepis), Patharchatti (Chagunius chagunio), Zebra (Danio rerio), Asala (Schizothorzx richardsonii), Bucche asala (Schizothorax plagiostomus), Chuche asala (Schizothoraicthy progastus), and Raajbam (Anguilla bengalensis).

\section{Socio-cultural values}


Wetlands have a special historical and cultural importance in Nepal. The name of the country 'Nepal' is perhaps derived from the Maithili word 'Nipal' meaning "a sacred piece of land cleansed by the holy rivers Mahakali, Koshi, Gandaki, Bagmati, etc." The river floodplains in Nepal are important sites of culture and history. The river banks are the sites for cremating the dead bodies as per the Hindu tradition. People bathe in holy streams/ponds and the famous Chhathi festival of Nepal is celebrated in the wetlands (rivers and ponds). These are also important as bird's paradise, tourist destination, river rafting and source of irrigation water.

The most important values of wetlands for human use in Nepal include water retention, replenishment of underground aquifers, and water quality improvement by removing or retaining nutrients, processing organic wastes, and reducing sediment before it reaches open water. Wetlands are crucial for food production - rice, fish and several types of vegetables; for the occurrence of medicinal plants, wild food, etc.; and for the wild genetic sources of agrobiodiversity.

The fisher-folk and other ethnic communities depend on wetlands for fishing, river transport, and traditional crafts produced from wetland plants - Korhila (Aeschynomene asper), Pater (Typha angustifolia), Mothi (Cyperus procerus), Baint (Calamus tenuis), and Siki (Vetiveria zizanioides). These wetland dependent communities are some of the poorest and most marginalized people in Nepal. Reduced access to wetlands, loss and degradation of wetlands, increasing population and lack of alternative livelihood options are some of the key challenges for these communities.

\section{Threats to wetlands}

There are a number of threats to wetlands in Nepal. These can be broadly categorised as habitat destruction and degradation, loss of ecosystem integrity, and depletion of species abundance and diversity.

The human population (nearly 30 million) of Nepal has a growth rate of $2.5 \%$ per year. Since $81 \%$ of the population is engaged in agriculture, demand for the modification of wetlands to agricultural land, particularly paddy fields, will continue to increase, placing additional pressure on wetlands. Further, as wetlands are relatively inexpensive compared to farmland, they are often the favoured sites for reclamation for industrial use or housing in urban areas.

Many of the wetlands of Terai region have no perennial source of water and they depend solely upon the monsoon rains. The draining of these wetlands, often by highpowered pumps to provide irrigation or harvest fish, leads to rapid drying out when at best they undergo vegetation changes and at worst are encronched upon for grazing or reclaimed for agriculture. The higher than average population growth rate in the Terai districts, stemming largely from high levels of immigration, has resulted in increasing pressure upon wetlands and forests that have become increasingly degraded and fragmented. This fragmentation has the effect of reducing previously extensive populations, especially of mammals and large reptiles, into genetically isolated subpopulations, many of which now risk falling below the threshold of population viability.

The four major rivers of Nepal Mahakali, Karnali, Gandaki and Sapta Koshi - are viewed widely as a great potential source of hydro-electric power. However, the construction of dams poses a major threat to wetland biodiversity by 
inundating important habitats; by reducing downstream water flows and thus distrubing the nutrient dynamics; displacing people into new ecologically-sensitive habitats; and, by altering local microclimates.

Management of rivers to control flooding and to provide water for largescale, dry-season irrigation involves construction of low-gated dams or barrages which isolate wildlife populations leading to reduced genetic transfer and associated inbreeding depression.

Growing human population and increasingly polluted surface water mainly due to the discharge of industrial effluents make groundwater the main source for domestic and other water requirements, particularly for irrigation. Lack of institutional control over usage to ensure adequate recharge, coupled with the lack of monitoring, has resulted in haphazard drilling of deep tube wells by big hotels and industrial and commercial establishments.

The emphasis on high -value crops and commercial agriculture has greatly accelerated the use of agro-chemicals in Nepal. Although the use of DDT for agricultural purposes is banned in Nepal, many other chemicals including Dieldrin, Aldrin, and Endrin classified as severely hazardous (Rotterdam Convention) are still commonly used throughout the country. Alternatives such as Caldan and Nukil are not available easily (IUCN 2004). Often, due to lack of understanding and a wish to increase crop production, these agro-chemicals are applied in excessive doses. These toxins runoff into water bodies to be absorbed by aquatic organisms. Bioaccumulation of these in many higher tropic level animals leads to high concentrations of toxic products causing death or sub-lethal effects such as reduced reproductive capability and making them unsafe for human consumption.

Pesticides (Phoret, Thiodan, Methyl parathion, Cypermethrin) are used for poisoning birds (both to prevent crop predation and for use as food) and in fishing bait. Their use has also been reported in illegal poaching for the wildlife trade. Department of Agriculture (Government of Nepal) has initiated an Integrated Pest Management (IPM) system combining mechanical, biological, and chemical methods of pest control with a view to minimizing the harmful effects of toxic pesticides on humans and the environment.

The use of inorganic fertilizers is increasing throughout Nepal resulting in high nutrient runoff that causes eutrophication, and oxygen depletion; accelerates seral succession towards mesic/dry land; and possibly facilitates disease spread. Epizootic Ulcerative Syndrome (EUS), a disease caused by the fungus Aphanomyces invadans in the internal tissue of fish, has been reported in Nepal since 1983. The source of contamination and the causative agent of EUS in Nepal are not known, but deterioration of water quality in water bodies provides favourable environmental conditions for the growth of $A$. invadans in fish.

Disposal of untreated industrial effluents and domestic sewage in rivers and wetlands around many large towns, leaked septic tanks, etc. also pollute the shallow groundwater aquifers (dug wells, shallow hand pumps). During the monsoon, an average faccal coliform count of 4404 $\mathrm{col} / 100 \mathrm{ml}$ was reported from the dug wells of Kathmandu valley. Not only the faecal coliform but also high concentrations of 
nitrate / ammonia, iron and manganese are reported for the water from dug wells of Kathmandu valley (IUCN 2004).

Asia's rivers are by far the greatest contributors of sediment, possibly supplying up to $80 \%$ of the world total. The combined Ganges - Brahmaputra Basin ranks first, with an estimated sediment yield of 2.4 billion tonnes $(15 \mathrm{t} / \mathrm{ha} / \mathrm{yr})$, of which the Ganges alone contributes three-quarters (11.3 t/ha/yr), vastly higher than such tropical rivers as Mekong (2.1 t/ha/yr) and the Orinoco $(0.9 \mathrm{t} / \mathrm{ha} / \mathrm{yr})$ of South America (Holeman 1968, Milliman and Meade 1983). The total Ganges system is estimated to carry approximately 430 million tonnes of sediment per year for a unit area denundation rate slightly over $400 \mathrm{t} / \mathrm{km}^{2} / \mathrm{yr}$ (Holeman 1968). Of the total volume of sediment passing through the Ganges system annually, it has been estimated that 170 million tonnes $(40 \%)$ is contributed by the Koshi River - at a unit area denudation rate of $2270 \mathrm{t} / \mathrm{km}^{2} / \mathrm{yr}, 3.5$ times that of the upper Indus Basin. In general, point source sediment contributions, caused by mass wasting, are the major source of sediment for most Himalayan rivers; and, the highest sediment concentrations are associated with high flood discharges.

Forests are under pressure from increasing human population and their demands for fuel-wood, timber, leaf litter (Seula), and other forest products. Over $75 \%$ of the energy resources and over $40 \%$ of fodder needs are met through forests. Felling of Sakhuwa (Shorea robusta) and clearing of riverine forests for trade and domestic uses as well as collection of biomass (leaf litter, fodder, medicinal and aromatic plants, etc.) have led to the depletion of forest cover and availability of these resources in the Terai lowland of Nepal. It is projected that all the
Terai forests would be cleared by 2075 if the current annual rate of deforestation of $1.3 \%$ continues unabated.

Traditional socio-cultural and agricultural practices in the Terai fabour high cattle populations. This has exacerbated grazing pressure on limited grasslands and forests through a proliferation of unproductive animals. Intensive year-round grazing in forests disrupts the regeneration of trees and impoverishes the ground flora. The changed botanical composition associated with reduction in palatable species results in scarcity of food for ungulates forcing them to raid agricultural crops in the surrounding areas. Overgrazing also leads to disturbance in bird habitat through the destruction of the nests of ground-dwelling species (Bengal florican and swamp partridge, for example) and destruction of the habitat of tall grass specialists (striated grassbird, Hodgson's bushchat, etc.). Overgrazing and movement of livestock along the shoreline contribute to soil erosion and high inputs of nitrogenous nutrients into the wetlands, resulting in elevated eutrophication of water and excessive growth of certain aquatic plant species, which again leads to loss of suitable habitat for birds and other aquatic life. Further, concentrated grazing by domestic livestock is inimical to the interest of wildlife, since the wildlife can never compete successfully with domestic stock under ordinary circumstances, and domestic animals transmit contagious diseases to wildlife like foot and mouth disease, rinderpest, surra (sleeping sickness), haemorrhagic septicaemia, anthrax, etc.

Poaching is widespread in Nepal, often for subsistence purposes, to supplement either meager diets or inadequate alternative livelihood opportunities. Ineffective law 
enforcement and insufficient conservation awareness are contributory factors. Poachers use traps, snares, spears, electric current, guns, explosives, and pesticides to kill targeted species. In addition to subsistence use, various live animals are sold as pets or food, and parts of dead animals for food, medicine and for a variety of decorative purposes.

Use of small-mesh sized fishing nets (a widespread practice in Nepal), electric current, and introduction of poisonous or explosive materials into water results in the removal of both adult breeding stock and young fingerlings from the fish populations, thereby reducing the possibilities of future breeding and recruitment from the affected areas. Further, draining of entire small/shallow wetlands to harvest all fish and aquatic products is an unsustainable method since it causes the loss of feeding and breeding sites of other species and causes habitats to undergo ecological succession towards mesic to dry land.

The removal of driftwood and associated debris from riverbeds and banks for fuel wood, and unregulated mining of sand, gravel and rocks for construction purposes and road building decreases river productivity, alters the hydraulics and substrate composition, and eliminate essential habitat for several fish species during all or part of their life cycle, thereby endangering fish populations and the aquatic wildlife that depend on them.

\section{Management policy}

Nepal's Commitment to environmental conservation is enshrined in its constitution (1990) under chapter 4, which states: "Nepal will give priority to raising public awareness on environmental issues, to mitigating the adverse effects the developmental works have on the environment, and to the conservation of rare fauna and flora." Nepal is also signatory to several Multilateral Environment Agreements (MEAS) of which three can be considered the most important for wetland biodiversity conservation - Convention on Wetlands of International Importance especially as Waterfowl Habitat (Ramsar 1971), Convention on Biological Diversity (CBD 1992), and Convention on International Trade in Endangered Species of Wild Fauna and Flora (CITES 1973). Nepal has several legal and institutional arrangements relevant to wetland management. These include the Constitution of Nepal (1990), Nepal Treaty Act, Local Self Governance Act, Forest Act, Water Resources Act., Electricity Act, National Parks and Wildlife Conservation Act, Aquatic Life Conservation Act, Soil and Watershed Management Act, Environment Protection Act, etc. Recently, National Wetland Policy (2003) has been formulated to manage wetlands in participation with local people and community. Today, Nepal has four Ramsar sites - Koshi Tappu Wildlife Reserve, Ghodaghodi Lake Area, Jagdishpur Reservoir, and Beeshazar Lake System; and IUCN's Species Survival Commission (SSC) has recommended creation of an International Biodiversity Conservation zone on a stretch of the Karnali river between Golaghat in Nepal and Katarniyaghat in India for the conservation of aquatic species (Smith et al. 1996). However, insufficiency of budgetary allocation, paucity of survey and research information for scientific management, apathetic and lethargic attitudes of the concerned officials, corruption and irregularity induced from various levels of the government and society, and above all, 
lack of people's participation frustrate the fulfillment of aims and objectives of all these noble management policies.

\section{General considerations}

The unsustainable use of wetland resources is prevalent throughout Nepal. Poverty is widespread and rates of population growth are high. Since most communities have weak, un-diversified, and insecure local livelihood based mostly on the direct exploitation of natural resources, people have little or no option in their patters of exploitation. Wetlands have many stakeholders at the community level with diverse interests, and overlapping government jurisdiction and a lack of policies and programmes to support community empowerment for their management means that government and communal wetlands are often used as 'open space' areas. Benefits from wetland resources accrue mostly to relatively wealthy local households - usually by grazing, water abstraction for irrigation, and from District Development Committee (DDC) and Village Development Committee (VDC) contracts for farming commercial fish. Poorer wetland-dependent, indigenous communities and households are not given the opportunity or the responsibility for wetland management, or given the opportunities for pursuing alternative livelihoods. Consequently, even though these poorer households recognize the implications of their unsustainable use, over-harvesting of plant and animal products remains commonplace simply because there are no alternatives.

The recognition of water as a scarce resource for Nepal, due largely to its highly variable seasonal and geographical distribution across the country highlights the role of wetlands as water stores. Fortunately, the important role of many communal wetlands (such as rivers and lakes) for local livelihoods, especially for some of the poorest and most marginalized communities, are also being better understood and recognized in Nepal, as are the cultural, spiritual and heritage aspects of wetlands. The role of wetlands in pollution abatement, especially through the use of artificial wetlands, is also being promoted in some urban areas of Nepal. Wise wetland use is therefore being recognized as a means for poverty reduction and improved human well-being.

\section{REFERENCES}

Aizaki, M., A. Terashima, H. Nakahara, T. Nisho and Y. Ishida 1987. Trophic status of Tilicho, a high altitude Himalayan lake. Hydrobiologia 153: $217-$ 224.

Ambasht, R.S. 1971. Ecosystem study of a tropical pond in relation to primary production of different vegetation zones. Hydrobiologia 12: 57-61.

Bernard, J.M. 1998. Population biology of wetland plants. In: Ecology of wetlands and associated systems (Eds. S.K. Majumdar, E.W. Miller and F.J. Brenner). The Pennsylvania Academy of Science, Easton, P.A. pp: 228-239.

Brooks, R.P. 1989. An overview of ecological functions and economic values of wetlands. In: Wetland ecology and conservation: Emphasis in Pennsylvania (Eds. S.K. Majumdar, R.P. Brooks, F.J. Brenner and R.W. Tiner) The Pennsylvania Academy of Science, Easton, P.A. p: 395.

Dangol, N.S. and P. Lacoul 1996. Growth and clump maintenance of Potamogeton crispus L. in Punyamati river, Panauti, Nepal. In: Environment and biodiversity:Iin the context of South Asia ( Eds. P.K. Jha, G.P.S. Ghimire, S.B. Karmacharya, S.R. Baral and P. Lacoul) Ecological Society (ECOS), Kathmandu. pp:141-147.

DOAD (Department of Agriculture Development) 1992. National fisheries development plan, 1992/93. Fisheries Development Division, DOAD, HMG/Nepal, Kathmandu.

Hanisch, D.M. 1998. The Thulagi glacial lake, Manaslu Himal, Nepal- hazard assessment of a 
potential outbrust. In: Proceedings of $8^{\text {th }}$ International Conference of International Association for Engineering Geology and the Environment (Eds. D. Monre and O. Hungr), 2125 September 1998, Vancouver. pp: 2209-2215.

Holeman, J. 1968. The sediment yield of major rivers of the world. Water Resources Research 10: 737-747.

IUCN (The World Conservation Union). 2004. A review of the status and threats to wetlands in Nepal. IUCN/Nepal, Kathmandu.

James, A. and J. Hubbick 1969. Studies on some high altitude lakes in the Hindukush Himalaya. Verh International Verein Limnology 17: 362-372.

Jha, S., U. Koirala and B. Niraula 2005. Plant resources of Betana Taal and adjoining areas. Report, Association for Protection of Environment and Culture (APEC), Biratnagar.

Jhs, S., U. Koirala and M.K. Khadka 2004. Enumeration and human use of the vascular plants of Chimadi lake and adjoining areas. Report, Forum for Protection of Public Interest (Propublic), Regional Office, Biratnagar.

Joshi, A.R. and D.P. Joshi 1991. Endemic plants of Nepal Himalaya: Conservation status and future direction. Mountain Environment and Development 1(2): 1-35.

Kaul, V. 1971. Production and ecology of some macrophytes of Kashmir lakes. Hydrobiologia 12: 63-69.

Loffler, H. 1969. High altitude lakes in the Mount Everest region. Verh International Verein Limnology 17: 373-385.

McEachern, P. 1994. Limnology and the natural wetlands survey. In: Safeguarding wetlands in Nepal (Eds. B. Bhandari, T.B. Shrestha and P. McEachern ), IUCN/Nepal, Kathmandu. pp: 89-103.

Milliman, J.D. and R.H. Meade 1983. Worldwide delivery of river sediments to the oceans. The Journal of Geology 91: 1-21.

Oliver, J.C. and R.J. Hill 1998. Foreword. In: Ecology of wetlands and associated systems (Eds. S.K. Majumdar, E.W. Miller and F.J. Brenner). The
Pennsylvania Academy of Science, Easton, P.A. pp: I-III.

Ormerod, S.J., S.T. Buckton, P.A. Brewin, A. Jenkins, R.C. Johnson, U. Juttner and A. Suren 1996. Biodiversity, chemistry and structure in streams of the Nepalese Himalaya. In: Proceedings International Conference on Ecohydrology of High Mountain Areas (Eds. S.R. Chalise and N.R. Khanal ). ICIMOD, Kathmandu. pp: 197-200.

Rai, D.N. 1980. Ecological structure of certain swamps of Darbhanga (Bihar). Bhagalpur University, Bhagalpur (Ph.D. Thesis).

Rai, D.N. and U.K. Sharma 1991. Phytocoenological structure and classification of wetlands in north Bihar. In: Aquatic sciences in India (Eds. B. Gopal and V. Asthana). Indian Association for Limnology and Oceanography, New Delhi. pp: 111-116.

Sankhala, K. 1990. Gardens of God: The waterbird sanctuary at Bharatpur. Vikas Publishing House, New Delhi.

Sharma, U.P. 1996. Ecology of the Koshi river in Nepal- India (north Bihar): a typical river ecosystem. In: Environment and biodiversity: In the context of South Asia (Eds. P.K. Jha, G.P.S. Ghimire, S.B. Karmacharya, S.R. Baral and P. Lacoul). Ecological Society (ECOS), Kathmandu. pp: 92-99.

Sinha, A.B. 1969. Investigation on the ecology of Ramgarh lake., Gorakhpur University, Gorakhpur (Ph.D. Thesis)

Smith, B.D., B.B. Bhandari and K. Sapkota 1996. Aquatic biodiversity in the Karnali and Narayani river basins-Nepal. IUCN/Nepal, Kathmandu.

WBC Nepal (Society for Wetlands and Biodiversity Conservation, Nepal) 2005. Conservation and sustainable use of Beeshazar lake system. WBC Nepal, Kathmandu.

WECS (Water and Energy Commission Secretariat) 1994. Proceedings of the $40^{\text {th }}$ Meeting of water and energy commission. HMG/Nepal, Kathmandu. 